\title{
EFFECT OF DIFFERENT STORAGE VESSELS ON VARIOUS TYPES OF WATER IN KOTA CITY
}

\author{
Porush Kumar \\ M. Tech Scholar, \\ Department of Civil Engineering \\ Rajasthan Technical University, \\ Kota, Rajasthan
}

\author{
Dr. Vaibhaw Garg \\ Associate Professor \\ Department of Civil Engineering \\ Rajasthan Technical University, \\ Kota, Rajasthan
}

\begin{abstract}
The present study identifies the change in drinking water quality and the observation of storage containers under different conditions. Drinkable water from three different resources viz. tap water, aquaguard water, and hand pump water were stored separately in three different types of storage containers under the observation period 30 days. Plastic bottles, steel jugs, and clay pots are used for this purpose. Water samples collected from different resources of drinking water are stored in different types of storage vessels and analyzed in the summer and rainy season after 30 days. The water quality parameters, such as TDS, EC, pH, Nitrate, DO, Total Hardness, were subjected to observation. The results obtained from this study indicate that the clay pot is found perfect among all types of storage vessels for storing drinking water for a long duration because it shows almost negligible deterioration in the drinking water characteristics.
\end{abstract}

\section{INTRODUCTION}

The majority of the world's population still uses unregulated, untreated drinking water such as hand pump water, bore well water, open well water, etc. Sobsey et al. (2003) clearly suggested from their work that small amounts of drinking water are collected and stored by the consumer at home. In India, villages and cities have additional problems due to the fixed timing of piped water supply, resulting in the need for water for drinking, cooking and washing purposes. Water storage has been suggested as a water purification system, treated or disinfected water may also be polluted during storage due to improper handling. Prescott et al. (1999) emphasized that preserving the quality of drinking water during storage is necessary for the protection of human health.

Clay pots have been commonly used since a long time ago to conserve water and keep the water clean. Plastic, steel, etc. containers are now widely used by customers to store water. Gadgil et al. (1998) noticed from their work that plastic and galvanized steel tanks are commonly used in urban areas while plastic and clay are commonly used in rural areas. Besides, the reality is that these products have no antimicrobial or cleaning properties. Chauhan et al. (2009) informed that people focus on current water purification systems and processes rather than inexpensive and straightforward traditional methods. Nowadays, People have generally started using aquaguard and reverse osmosis systems to purify water. Water storage containers are made of a variety of materials including clay, concrete, galvanized steel, wood, fiberglass, and polyethylene plastic. Georgia et al. (1999) clearly suggested that plastic tanks are the most commonly used with its advantage being low cost, durability and of low maintenance.

\section{A. Indian Standard Data of Parameters}

Indian standard data of parameters according to BIS, which is analyzed in this study shown in table 1 .

Table 1:- Indian standard data of parameters

\begin{tabular}{|l|c|c|}
\hline \multicolumn{3}{|c|}{ INDIAN STANDARD OF PARAMETERS } \\
\hline PARAMETER & $\begin{array}{c}\text { Requirement } \\
\text { (Acceptable } \\
\text { Limit) }\end{array}$ & $\begin{array}{c}\text { Permissible Limit In } \\
\text { The Absence Of } \\
\text { Alternate Source }\end{array}$ \\
\hline $\mathrm{Ph}$ & $6.5-8.5$ & No relaxation \\
\hline TDS $(\mathrm{mg} / \mathrm{l})$ & 500 & 2000 \\
\hline Conductivity $(\mu \mathrm{s} / \mathrm{cm})$ & 200 & 800 \\
\hline DO(mg/l) & 6 & No relaxation \\
\hline Hardness $(\mathrm{mg} / \mathrm{l})$ & 200 & 600 \\
\hline Nitrate $(\mathrm{mg} / \mathrm{l})$ & 45 & 100 \\
\hline
\end{tabular}

\section{B. Study Area}

Kota, "the educational city of Rajasthan (India)", is situated on the bank of Chambal River. Kota is going to face acute drinking water woes in the future. Extension of Kota city, population growth due to rapid urbanization, and the students coming here from all over India to the preparation of competitive exams such as IITs, AIIMS, etc., government negligees is the main reason behind it.

\section{Aim of the Study}

The primary objective of this research is to store drinking water in a perfect storage vessel as long as possible without deterioration in its qualities. Indian Standard has considered all the types of storage vessels mentioned above useful in storing potable water. The fact remains that they come in a variety of colors, and the maximum retention periods for storing water in these tanks are not usually stated. Hence, it is still necessary to investigate how each type of storage tank affects the quality of the water stored in it. The current work examined the impact of various storage containers on the quality of water, thereby can be preserving and promoting human health. 


\section{International Journal of Engineering Applied Sciences and Technology, 2020 Vol. 4, Issue 9, ISSN No. 2455-2143, Pages 485-490 \\ Published Online January 2020 in IJEAST (http://www.ijeast.com)}

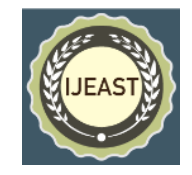

\section{RELATED WORK}

Many researchers have carried out their studies on variation in drinking water parameters when stored in different kinds of storage vessels in India and abroad.

Mohanan et al. (2017) in their study investigated that the effect of different types of storage vessels such as plastic, glass, brass, copper, aluminium, steel, and clay on water quality and analyzed physicochemical and biological parameters of initial water and after storing the water in different vessels for 30 days. The results obtained in this study show that the quality of water filled in clay, brass and copper vessels is better than others.

Ogbozige et al. (2015) in their work observed that tap water and borehole water stored in twelve-water storage reservoirs (six for each water source) for six weeks. The tank consisted of black, blue and green plastic tanks, coated and uncoated steel metal tanks and clay pots. water quality parameters investigated such as temperature, color, total solids, EC, DO, chlorine residual, chloride, $\mathrm{pH}$, total hardness, alkalinity, manganese, and total heterotrophic bacteria (TBH) Was analyzed with a sampling frequency of seven-day intervals. Results show that the growth rate constant of Manganese concentration in water stored in plastic tanks, coated steel metal tanks, uncoated steel metal tanks, and clay pots are higher than permissible limits. The colour of both water sources stored in uncoated steel metal tanks above the permissible limits set by W.H.O Standard.

Anf H. Ziadat (2005) in his research work evaluate that one hundred water samples were collected from residential galvanized steel water storage tanks from three different areas of Al-Karak province in the southern part of Jordan country. Samples were analyzed for major anions $\left(\mathrm{HCO}_{3}, \mathrm{~F}^{-}, \mathrm{Cl}^{-}, \mathrm{NO}_{3}^{-}\right.$ and $\left.\mathrm{SO}_{4}^{-2}\right)$, major cations $\left(\mathrm{Na}^{+}, \mathrm{K}^{+}, \mathrm{Ca}^{2+}\right.$, and $\mathrm{Mg}^{2+}$ ) and heavy metals $(\mathrm{Pb}, \mathrm{Fe}, \mathrm{Cu}, \mathrm{Zn}, \mathrm{Mn}$, and $\mathrm{Ni}$ ), in order to. The results obtained that the water quality of storage tanks showed higher ionic concentrations in comparison to its source.

Majesty et al. (2013) in their study investigated that the effect of storage vessels on water quality. They used vessels made from glass, plastic, metal, calabash and clay pot for this study. The results obtained in this study showed that some physicochemical parameters and metals of water contained in some of the storage vessels were significantly (clay pot > metal vessel $>$ plastic vessel $>$ glass vessel).

Cynthia et al. (2012) in their work addressed issues that the water quality of household water investigated in storage tanks in Tiquipaya, Bolivia. Storage tanks cleaned three or more times per year had statistically less Escherichia coli and turbidity than tanks cleaned less frequently. The results obtained that there was a statistically significant difference between $\mathrm{E}$. coli counts in tanks cleaned three or more times per year compared with storage tanks cleaned less than once per year $(p=0.01)$. The tank age has little effect on water quality.

Chalchisa et al. (2017) in their study examined that all water samples collected from drinking water examined in storage tanks were positive for total coliforms and faecal coliforms.
The result showed that the drinking water was microbially contaminated in all sampling points. The level of microbial contamination increased from before entering the storage tank after leaving the storage tank, indicating that the presence of leakage in the distribution system and contamination at the storage tanks. The turbidity was found in the safe water quality range (2.1-2.9 NTU).

Naddafi et al. (2005) in their work determined that the efficiency of clay pots (as a filter) in removing water impurities. Pilot and the related clay parts were manufactured, and its efficiency in removing TDS, hardness, $\mathrm{NO}_{3}{ }^{-}$, colour, and turbidity was measured by passing water through the clay pipes. The results showed that the clay filters had not the potential to remove hardness, EC, TDS and nitrate of water. However, they showed excellent efficiency in turbidity removal $(\geq 90 \%)$ and could significantly decrease the colour of the water $(\geq 60 \%)$.

\section{MATERIALS AND METHODS}

Variation in drinking water quality in storage vessels with time is a serious concern to human health. sample preparation in different storage vessels took place and subjected to analysis.

\section{A. Sampling of Water}

The sampling of water is done in two periods first is the summer season (June 2019) and the second is the rainy season (July 2019) for measurement of parameters. The tap water sample was collected from the household service line tap at Ganesh Nagar Kota and the aquaguard water sample was collected from the public water cooler at Kota city. The groundwater sample was collected from a handpump situated in Ganesh Nagar Kota. All collected samples were stored in three separate vessels, including steel vessels, clay pots, and plastic bottles. The collected water samples were allowed to remain in storage vessels for 30 days, and the analysis was carried out after 30 days.

The physicochemical parameters, including $\mathrm{pH}, \mathrm{EC}$, total hardness, nitrate, total dissolved solids (TDS), and dissolved oxygen (DO), were analyzed using the digital method and water test kit method.

\section{B. Storage Vessels For Sampling \\ 1. Clay Pots}

Water samples collected from the tap, aquaguard, and hand pump are stored in the clay pots (shown in fig. 1 below) for 30 days in summer and rainy season. The samples stored in clay pots to check the effect of clay pot material on water quality.

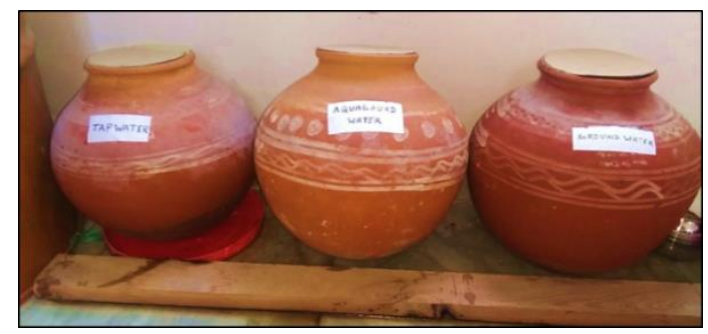

Figure 1:- Drinking water sample in the clay pots 


\section{International Journal of Engineering Applied Sciences and Technology, 2020 \\ Vol. 4, Issue 9, ISSN No. 2455-2143, Pages 485-490 \\ Published Online January 2020 in IJEAST (http://www.ijeast.com)}

\section{Plastic Bottles}

Water samples collected from the tap, aquaguard, and hand pump are stored in the plastic bottles (shown in fig. 2 below) for 30 in summer and rainy season. The samples stored in plastic bottles to check the effect of storage material on water quality.

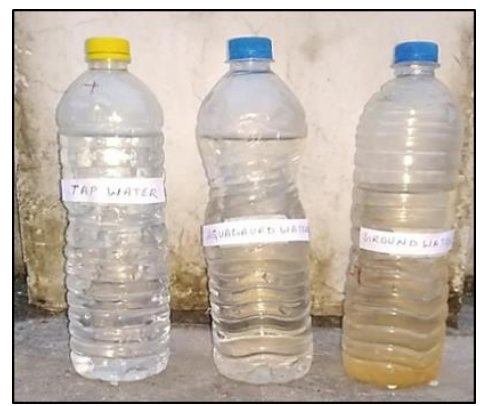

Figure 2:- Drinking water sample in the plastic bottles

\section{Steel Vessels}

Water samples collected from the tap, aquaguard, and hand pump are stored in the steel vessels (shown in fig. 3 below) for 30 days in summer and rainy season. The samples stored in vessels to check the effect of steel material on water quality.

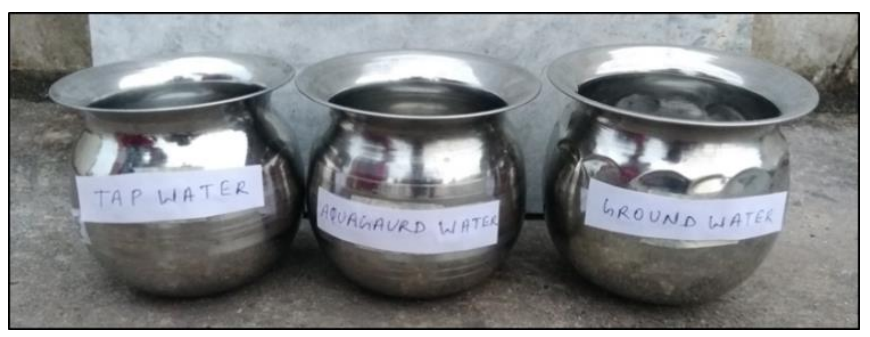

Figure 3:- Drinking water sample in steel vessels

\section{Observation period and Parameters}

Drinking water collected from the sources tap, aquaguard, and hand pump is stored in three different storage vessels, including steel, clay pot, and plastic vessel (three for each water source) for 30 days. The observation carried out after 30 days. The parameters, including $\mathrm{pH}$, TDS, EC, DO, Total hardness, and Nitrate, were examined during the period of sampling.

All the parameters mentioned above were examined two times first in the summer season and second in the rainy season.

Observation carried out in two periods.

- Summer season: 1 June 2019 to 1 July 2019 (30 days)

- $\quad$ Rainy season: 5 July 2019 to 4 August 2019 (30 days)

Table 2:- Variation of tap, aquagaurd and hand pump water in different storage vessels in the summer season

\begin{tabular}{|c|c|c|c|c|c|c|c|c|c|c|c|c|c|}
\hline \multicolumn{14}{|c|}{ VARIATIONS OF PARAMETERS AFTER 30 DAYS IN SUMMER SEASON } \\
\hline \multirow{2}{*}{$\begin{array}{c}\text { TYPES OF } \\
\text { WATER }\end{array}$} & \multirow{2}{*}{$\begin{array}{l}\text { STORAGE } \\
\text { VESSEL }\end{array}$} & \multicolumn{2}{|c|}{$\mathbf{P}^{\mathrm{H}}$} & \multicolumn{2}{|c|}{ TDS (mg/l) } & \multicolumn{2}{|c|}{ Conductivity() } & \multicolumn{2}{|c|}{ DO (mg/l) } & \multicolumn{2}{|c|}{ Hardness(mg/l) } & \multicolumn{2}{|c|}{ Nitrate (mg/l) } \\
\hline & & Initial & Final & Initial & Final & Initial & Final & Initial & Final & Initial & Final & Initial & Final \\
\hline \multirow{3}{*}{ TAP WATER } & $\begin{array}{c}\text { STEEL } \\
\text { VESSEL }\end{array}$ & 7.5 & 9.2 & 60.12 & 50.2 & 220.6 & 215.6 & 5.75 & 6.92 & 150 & 110 & 20 & 20 \\
\hline & $\begin{array}{l}\text { CLAY } \\
\text { POT }\end{array}$ & 7.5 & 7.9 & 60.12 & 69.5 & 220.6 & 230.5 & 5.75 & 7.0 & 150 & 200 & 20 & 10 \\
\hline & $\begin{array}{l}\text { PLASTIC } \\
\text { BOTTLE }\end{array}$ & 7.5 & 6.65 & 60.12 & 54.6 & 220.6 & 176.9 & 5.75 & 4.20 & 150 & 150 & 20 & 25 \\
\hline \multirow{3}{*}{$\begin{array}{c}\text { AQUAGUARD } \\
\text { WATER }\end{array}$} & $\begin{array}{l}\text { STEEL } \\
\text { VESSEL }\end{array}$ & 7.0 & 9.1 & 60.1 & 54.6 & 221.5 & 221.7 & 6.94 & 6.35 & 200 & 130 & 15 & 15 \\
\hline & $\begin{array}{l}\text { CLAY } \\
\text { POT }\end{array}$ & 7.0 & 7.7 & 60.1 & 69.5 & 221.5 & 235.6 & 6.94 & 7.02 & 200 & 250 & 15 & 10 \\
\hline & $\begin{array}{l}\text { PLASTIC } \\
\text { BOTTLE }\end{array}$ & 7.0 & 6.2 & 60.1 & 46.3 & 221.5 & 180.2 & 6.94 & 5.2 & 200 & 200 & 15 & 12 \\
\hline \multirow{3}{*}{$\begin{array}{l}\text { HANDPUMP } \\
\text { WATER }\end{array}$} & $\begin{array}{c}\text { STEEL } \\
\text { VESSEL }\end{array}$ & 7.9 & 8.6 & 90.0 & 83.6 & 280.9 & 272.8 & 6.53 & 6.85 & 250 & 180 & 20 & 10 \\
\hline & $\begin{array}{l}\text { CLAY } \\
\text { POT }\end{array}$ & 7.9 & 7.7 & 90.0 & 87.3 & 280.9 & 278.6 & 6.53 & 7.3 & 250 & 200 & 20 & 5 \\
\hline & $\begin{array}{l}\text { PLASTIC } \\
\text { BOTTLE }\end{array}$ & 7.9 & 5.95 & 90.0 & 80.6 & 280.9 & 265.4 & 6.53 & 1.80 & 250 & 250 & 20 & 25 \\
\hline
\end{tabular}


International Journal of Engineering Applied Sciences and Technology, 2020

Vol. 4, Issue 9, ISSN No. 2455-2143, Pages 485-490

Published Online January 2020 in IJEAST (http://www.ijeast.com)

Table 3:- Variation of tap, aquagaurd and hand pump water in different storage vessels in the rainy season

\begin{tabular}{|c|c|c|c|c|c|c|c|c|c|c|c|c|c|}
\hline \multicolumn{14}{|c|}{ VARIATIONS OF PARAMETERS AFTER 30 DAYS IN RAINY SEASON } \\
\hline \multirow{2}{*}{$\begin{array}{c}\text { TYPES OF } \\
\text { WATER }\end{array}$} & \multirow{2}{*}{$\begin{array}{l}\text { STORAGE } \\
\text { VESSEL }\end{array}$} & \multicolumn{2}{|c|}{$\mathbf{P}^{\mathrm{H}}$} & \multicolumn{2}{|c|}{ TDS (mg/l) } & \multicolumn{2}{|c|}{ Conductivity } & \multicolumn{2}{|c|}{ DO (mg/l) } & \multicolumn{2}{|c|}{ Hardness(mg/l) } & \multicolumn{2}{|c|}{ Nitrate (mg/l) } \\
\hline & & Initial & Final & Initial & Final & Initial & Final & Initial & Final & Initial & Final & Initial & Final \\
\hline \multirow{3}{*}{ TAP WATER } & $\begin{array}{c}\text { STEEL } \\
\text { VESSEL }\end{array}$ & 7.4 & 8.9 & 61.6 & 68.2 & 221.4 & 252.8 & 6.17 & 6.93 & 100 & 160 & 20 & 20 \\
\hline & $\begin{array}{l}\text { CLAY } \\
\text { POT }\end{array}$ & 7.4 & 7.9 & 61.6 & 64.4 & 221.4 & 243.5 & 6.17 & 7.25 & 100 & 200 & 20 & 30 \\
\hline & $\begin{array}{l}\text { PLASTIC } \\
\text { BOTTLE }\end{array}$ & 7.4 & 6.7 & 61.6 & 54.7 & 221.4 & 220.2 & 6.17 & 5.02 & 100 & 100 & 20 & 5 \\
\hline \multirow{3}{*}{$\begin{array}{c}\text { AQUAGUARD } \\
\text { WATER }\end{array}$} & $\begin{array}{l}\text { STEEL } \\
\text { VESSEL }\end{array}$ & 7.1 & 8.8 & 61.4 & 59.8 & 220.6 & 232.7 & 6.35 & 6.95 & 100 & 150 & 20 & 20 \\
\hline & $\begin{array}{l}\text { CLAY } \\
\text { POT }\end{array}$ & 7.1 & 7.8 & 61.4 & 70.1 & 220.6 & 255.1 & 6.35 & 6.75 & 100 & 200 & 20 & 40 \\
\hline & $\begin{array}{l}\text { PLASTIC } \\
\text { BOTTLE }\end{array}$ & 7.1 & 6.2 & 61.4 & 53.3 & 220.6 & 217 & 6.35 & 5.23 & 100 & 100 & 20 & 10 \\
\hline \multirow{3}{*}{$\begin{array}{l}\text { HANDPUMP } \\
\text { WATER }\end{array}$} & $\begin{array}{c}\text { STEEL } \\
\text { VESSEL }\end{array}$ & 8.3 & 9.5 & 91.4 & 74.8 & 287.5 & 266.1 & 6.02 & 6.91 & 200 & 160 & 10 & 20 \\
\hline & $\begin{array}{l}\text { CLAY } \\
\text { POT }\end{array}$ & 8.3 & 7.5 & 91.4 & 88.5 & 287.5 & 296.7 & 6.02 & 7.10 & 200 & 150 & 10 & 20 \\
\hline & $\begin{array}{l}\text { PLASTIC } \\
\text { BOTTLE }\end{array}$ & 8.3 & 6.9 & 91.4 & 83.3 & 287.5 & 285.5 & 6.02 & 3.99 & 200 & 120 & 10 & 10 \\
\hline
\end{tabular}

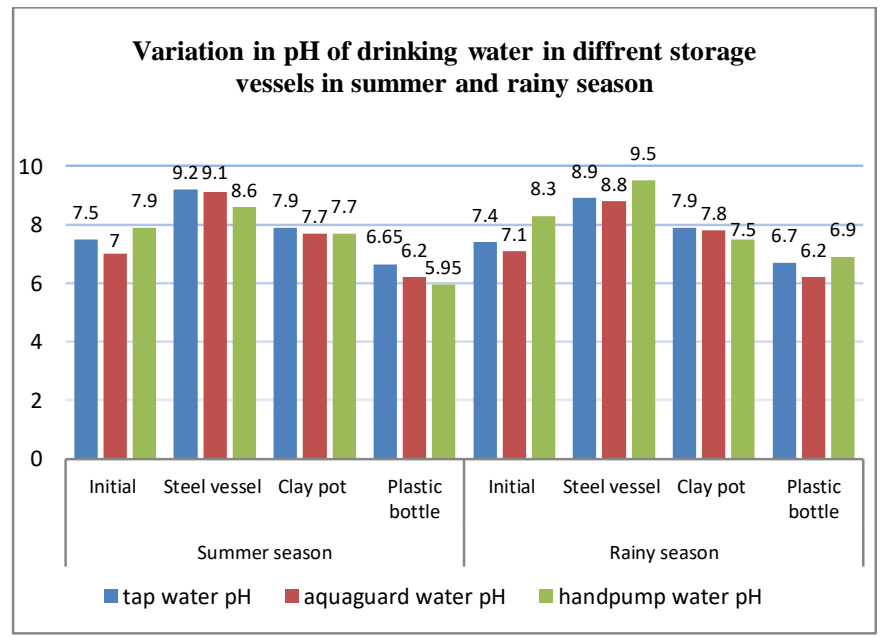

Figure 4:- Variation in $\mathrm{pH}$ of drinking water

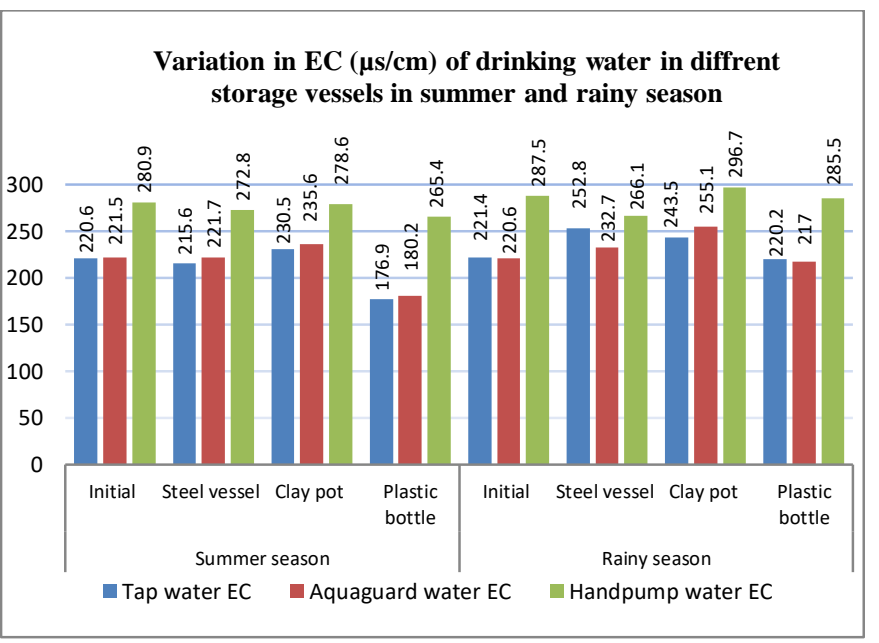

Figure 6:- Variation in EC of drinking water

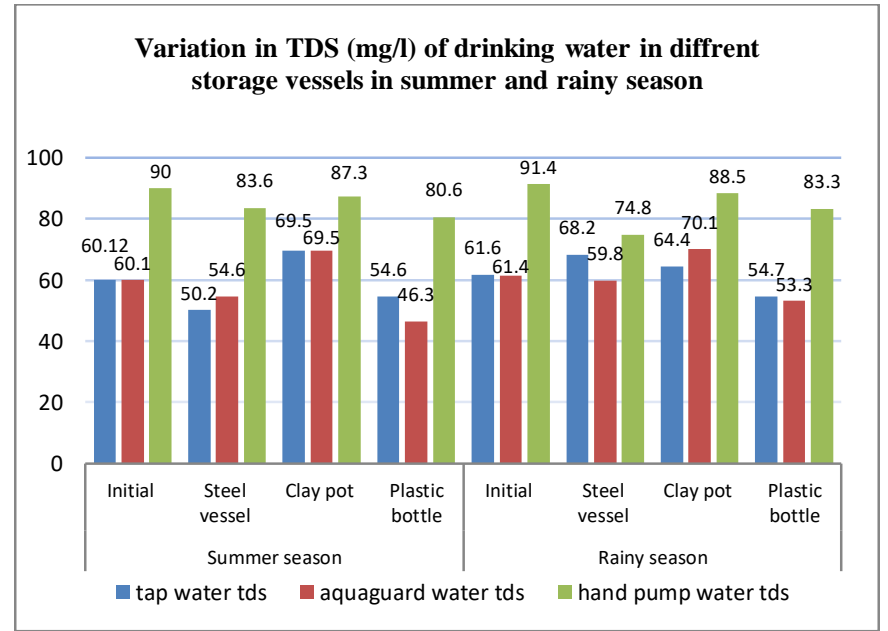

Figure 5:- Variation in TDS of drinking water

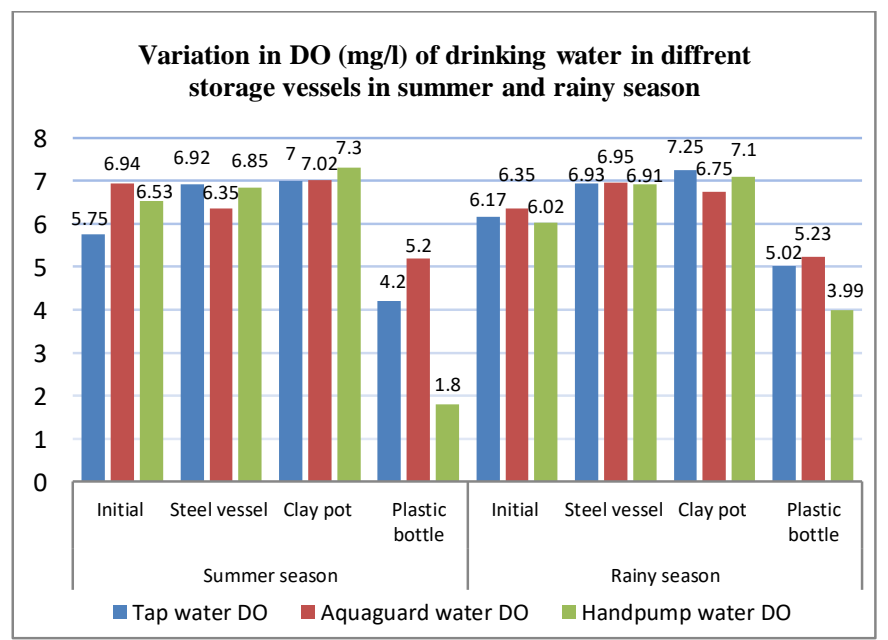

Figure 7:- Variation in DO of drinking water 


\section{International Journal of Engineering Applied Sciences and Technology, 2020 \\ Vol. 4, Issue 9, ISSN No. 2455-2143, Pages 485-490 \\ Published Online January 2020 in IJEAST (http://www.ijeast.com)}

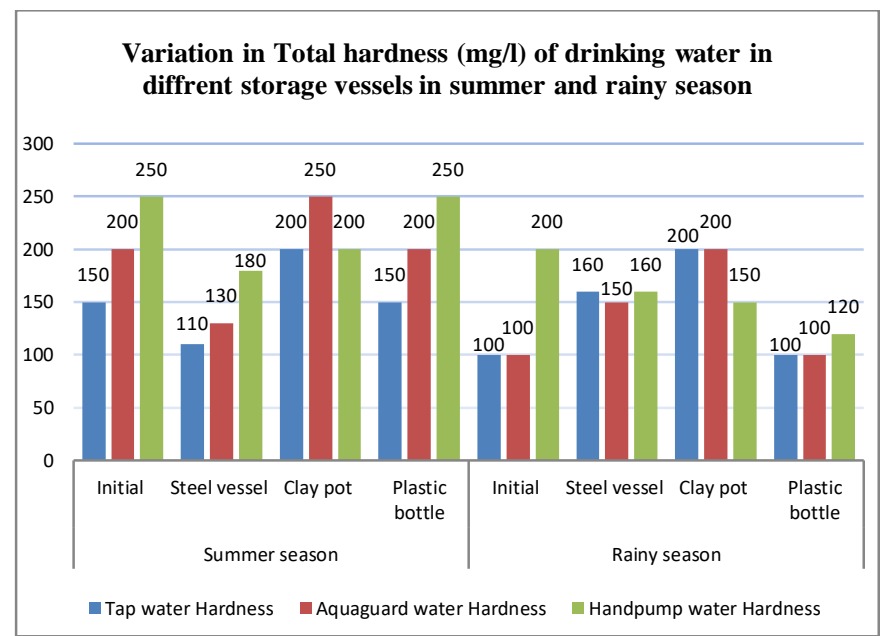

Figure 8:- Variation in Total Hardness of drinking water

\section{IV.RESULTS AND DISCUSSION}

The variations in the parameters such as $\mathrm{pH}$, TDS, EC, DO, Total hardness and nitrate in three types of water viz. tap water, aquaguard water, and hand pump water in the three types of storage containers (steel jug, clay pot, and plastic Bottle) in the summer and rainy season.

\section{$>\mathbf{P}^{\mathrm{H}}$}

In the summer season, the initial $\mathrm{pH}$ of the tap, aquaguard, and handpump were 7.5, 7 and 7.9, respectively. The $\mathrm{pH}$ of each water stored is observed to be high $\mathrm{pH}(9.2,9.1$ and 8.6, respectively) in the steel vessel, while the low $\mathrm{pH}(6.65,6.2$, and 5.95, respectively) is observed in the plastic bottle and slight changes in the clay pot (7.9, 7.7, and 7.7, respectively) is observed. In the rainy season, the initial $\mathrm{pH}$ of tap, aquaguard and handpump water was 7.4, 7.1, and 8.3 respectively. The $\mathrm{pH}$ of each water stored is observed to be high $\mathrm{pH}(8.9,8.8$, and 9.5 respectively) in steel vessel, while low $\mathrm{pH}(6.7,6.2$, and 6.9 respectively) observed in plastic bottle and slight changes in clay pot (7.9, 7.8, and 7.5 respectively) is observed. The $\mathrm{pH}$ increase due to the decrease in aqueous $\mathrm{CO}_{2}$ in the stored water of steel vessel, the clay pot is alkaline in nature, so it increases the $\mathrm{pH}$ of the water and the increase in aqueous $\mathrm{CO}_{2}$ decreased the $\mathrm{pH}$ of water in the plastic bottle.

\section{TDS}

In the summer season, the initial TDS of the tap, aquaguard, and handpump were $60.12 \mathrm{mg} / \mathrm{l}, 60.1 \mathrm{mg} / \mathrm{l}$ and $90 \mathrm{mg} / \mathrm{l}$, respectively. The TDS of each water stored is obtained high TDS $(69.5 \mathrm{mg} / \mathrm{l}, 69.5 \mathrm{mg} / \mathrm{l}$, and $87.3 \mathrm{mg} / \mathrm{l}$, respectively) in the clay pot, while low TDS $(50.2 \mathrm{mg} / \mathrm{l}, 54.6 \mathrm{mg} / \mathrm{l}$ and $83.6 \mathrm{mg} / \mathrm{l}$, respectively) in the steel vessel and observed $(54.6 \mathrm{mg} / \mathrm{l}, 46.3$ $\mathrm{mg} / \mathrm{l}$, and $80.6 \mathrm{mg} / \mathrm{l}$, respectively) in the plastic bottle. In the rainy season, the initial TDS of tap, aquaguard and handpump water was $61.4,61.4$, and 91.4 respectively. The TDS of each water stored obtained high TDS (68.2, 59.8, and 74.8 respectively) in steel vessel, while low TDS observed (54.7, 53.3 , and 83.3 respectively) in plastic bottle and observed $(64.4,70.1$, and 88.5 respectively) in the clay pot. TDS of

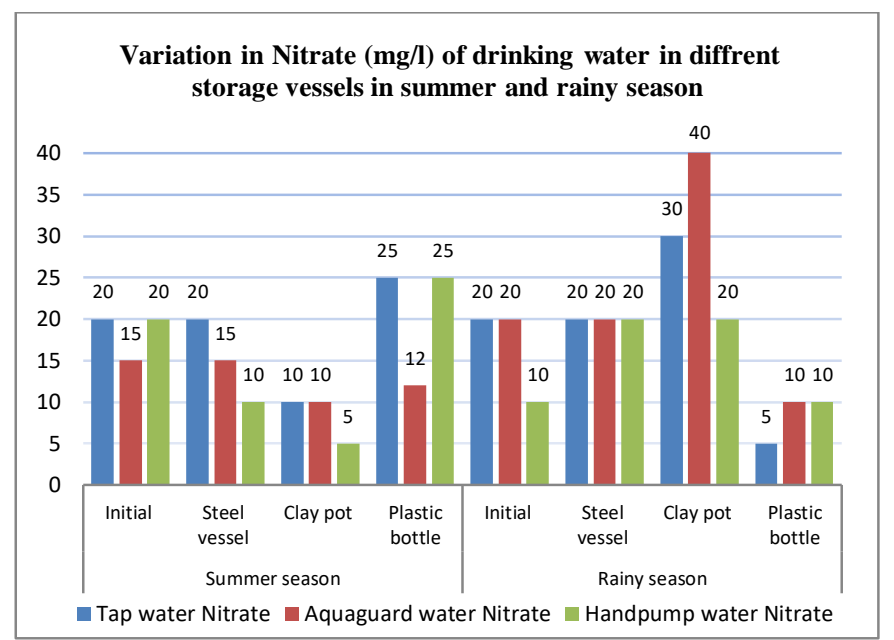

Figure 9:- Variation in Nitrate of drinking water

water increases in the clay pot, because mineral quantity gets higher because of clay properties and decreased in steel vessel or plastic bottle because of the number of minerals present in water settle down.

\section{$>\mathrm{CE}$}

In the summer season, the initial CE of the tap, aquaguard, and handpump were $220.6 \mu \mathrm{s} / \mathrm{cm}, 221.5 \mu \mathrm{s} / \mathrm{cm}$ and $280.9 \mu \mathrm{s} / \mathrm{cm}$, respectively. The $\mathrm{CE}$ of each water stored is shown to be high CE $(230.5 \mu \mathrm{s} / \mathrm{cm}, 235.6 \mu \mathrm{s} / \mathrm{cm}$, and $278.6 \mu \mathrm{s} / \mathrm{cm}$, respectively) in the clay pot. While the low EC $(176.9 \mu \mathrm{s} / \mathrm{cm}, 180.2 \mu \mathrm{s} / \mathrm{cm}$, and $265.4 \mu \mathrm{s} / \mathrm{cm}$, respectively) is shown in the plastic bottle and slight changes $(215.6 \mu \mathrm{s} / \mathrm{cm}, 221.7 \mu \mathrm{s} / \mathrm{cm}$ and $272.8 \mu \mathrm{s} / \mathrm{cm}$, respectively) in the steel vessel is shown. In the rainy season, the initial EC of tap, aquaguard and handpump water was $221.4 \mu \mathrm{s} / \mathrm{cm}, 220.6 \mu \mathrm{s} / \mathrm{cm}$, and $287.5 \mu \mathrm{s} / \mathrm{cm}$ respectively. The $\mathrm{EC}$ of each water stored is shown to be high EC $(252.8 \mu \mathrm{s} / \mathrm{cm}$, $232.7 \mu \mathrm{s} / \mathrm{cm}$, and $266.1 \mu \mathrm{s} / \mathrm{cm}$ respectively) in steel vessel. While low EC $(220.2 \mu \mathrm{s} / \mathrm{cm}, 217 \mu \mathrm{s} / \mathrm{cm}$, and $285.5 \mu \mathrm{s} / \mathrm{cm}$ respectively) shown in plastic bottle and slight changes in clay pot $(243.5 \mu \mathrm{s} / \mathrm{cm}, 255.1 \mu \mathrm{s} / \mathrm{cm}$, and $296.7 \mu \mathrm{s} / \mathrm{cm}$ respectively) is shown. EC and TDS of water are dependent on each other, so TDS increases then EC also increases in the clay pot and vice versa.

\section{DO}

In the summer season, the initial DO of the tap, aquaguard, and handpump were $5.76 \mathrm{mg} / \mathrm{l}, 6.94 \mathrm{mg} / \mathrm{l}$ and $6.53 \mathrm{mg} / \mathrm{l}$, respectively. The DO of each water stored is observed to be high DO (7 mg/l, $7.02 \mathrm{mg} / 1$, and $7.3 \mathrm{mg} / \mathrm{l}$, respectively) in the clay pot. While the low DO observe $(4.2 \mathrm{mg} / \mathrm{l}, 5.2 \mathrm{mg} / \mathrm{l}$, and $1.8 \mathrm{mg} / \mathrm{l}$, respectively) in the plastic bottle and slight changes observed $(6.92 \mathrm{mg} / \mathrm{l}, 6.35 \mathrm{mg} / \mathrm{l}$ and $6.85 \mathrm{mg} / \mathrm{l}$, respectively) in the steel vessel. In the rainy season, the initial DO of tap, aquaguard and handpump water was $6.17 \mathrm{mg} / \mathrm{l}, 6.35 \mathrm{mg} / \mathrm{l}$, and $6.02 \mathrm{mg} / \mathrm{l}$ respectively. The DO of each water stored is observed to be high DO $(7.25 \mathrm{mg} / \mathrm{l}, 6.75 \mathrm{mg} / \mathrm{l}$, and $7.1 \mathrm{mg} / \mathrm{l}$ respectively) in the clay pot. While low DO observe (5.02 $\mathrm{mg} / \mathrm{l}, 5.23 \mathrm{mg} / \mathrm{l}$, and $3.99 \mathrm{mg} / \mathrm{l}$ respectively) shown in plastic bottle and slight changes observed $(6.93 \mathrm{mg} / \mathrm{l}, 6.95 \mathrm{mg} / \mathrm{l}$, and $6.91 \mathrm{mg} / \mathrm{l}$ respectively) in the clay pot. The DO of water 


\section{International Journal of Engineering Applied Sciences and Technology, 2020 \\ Vol. 4, Issue 9, ISSN No. 2455-2143, Pages 485-490 \\ Published Online January 2020 in IJEAST (http://www.ijeast.com)}

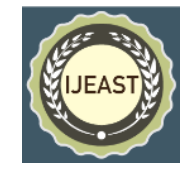

increases in steel or clay pot because tap water directly contacts with air. In addition, the plastic container is airtight, so the DO decreases over time in the plastic bottle because microorganisms consume DO for biological activity.

\section{TOTAL HARDNESS}

In the summer season, the initial Total Hardness of the tap, aquaguard, and handpump was $150 \mathrm{ppm}, 200 \mathrm{ppm}$ and 250 ppm, respectively. The Total Hardness of each water stored is obtained to be high (200 ppm, $250 \mathrm{ppm}$, and $200 \mathrm{ppm}$, respectively) in the clay pot. While the low (110 ppm, 130 ppm and $180 \mathrm{ppm}$, respectively) is obtained in steel vessel and slight changes obtained (150 ppm, $200 \mathrm{ppm}$, and $250 \mathrm{ppm}$, respectively) in plastic bottle. In the rainy season, the initial Total Hardness of tap, aquaguard and handpump water was $100 \mathrm{ppm}, 100 \mathrm{ppm}$, and $200 \mathrm{ppm}$ respectively. The Total Hardness of each water stored is obtained to be high $(200$ ppm, $200 \mathrm{ppm}$, and $150 \mathrm{ppm}$ respectively) in the clay pot. While low (100 ppm, $100 \mathrm{ppm}$, and $120 \mathrm{ppm}$ respectively) observed in plastic bottle and slight changes (160 ppm, 200 ppm, and $200 \mathrm{ppm}$ respectively) observed in steel vessel. The total hardness of water increases in the clay pot because hardness containing ions is present in the clay or minerals are provided during the manufacturing of pots.

\section{$>$ NITRATE}

In the summer season, the initial Nitrate of the tap, aquaguard, and handpump was $20 \mathrm{mg} / \mathrm{l}, 15 \mathrm{mg} / \mathrm{l}$ and $20 \mathrm{mg} / \mathrm{l}$, respectively. The Nitrate of each water stored is shown to be high $(25 \mathrm{mg} / 1,12 \mathrm{mg} / \mathrm{l}$, and $25 \mathrm{mg} / \mathrm{l}$, respectively) in plastic bottle. While the low Nitrate $(10 \mathrm{mg} / 1,10 \mathrm{mg} / \mathrm{l}$, and $5 \mathrm{mg} / \mathrm{l}$, respectively) is shown in the clay pot and slight changes (20 $\mathrm{mg} / \mathrm{l}, 15 \mathrm{mg} / \mathrm{l}$ and $10 \mathrm{mg} / \mathrm{l}$, respectively) shown in the steel vessel. In the rainy season, the initial Nitrate of tap, aquaguard and handpump water was $20 \mathrm{mg} / \mathrm{l}, 20 \mathrm{mg} / \mathrm{l}$, and $10 \mathrm{mg} / \mathrm{l}$ respectively. The Nitrate of each water stored is shown to be high $(30 \mathrm{mg} / \mathrm{l}, 40 \mathrm{mg} / \mathrm{l}$, and $20 \mathrm{mg} / \mathrm{l} \mathrm{respectively)}$ in the clay pot. While low Nitrate $(5 \mathrm{mg} / \mathrm{l}, 10 \mathrm{mg} / \mathrm{l}$, and $10 \mathrm{mg} / \mathrm{l}$ respectively) shown in plastic bottle and slight changes (20 $\mathrm{mg} / \mathrm{l}, 20 \mathrm{mg} / \mathrm{l}$, and $20 \mathrm{mg} / \mathrm{l}$ respectively) observed steel vessel.

\section{CONCLUSION}

This study concludes that the material of storage containers significantly affects the quality of the water with time. TDS, EC, pH, Total hardness, Nitrate, and DO of stored water are changed in the steel, clay pot, and plastic vessel. The storage vessel viz. plastic bottle significantly affects the DO of handpump water and affects the quality of the water.

The water quality parameters of all water sources stored in the steel vessel and plastic bottle (tap water, aquaguard water, and handpump water) are subject to extreme changes over time, which decreases the water quality. Oppositely, there is relatively less change in the water parameters in the clay pot, which not decreases the water quality.

\section{ACKNOWLEDGEMENT}

I would like to express my special thanks of gratitude towards RTU, Kota for the scholarship being awarded during the period of M.tech.

\section{REFERENCE}

[1] Sobsey, M.D., Handzel, T., and Venczel, L. (2003): Chlorination and safe storage of household drinking water in developing countries to reduce waterborne disease, Water Science and Technology. 47:221-228.

[2] Prescott, L.M., Harley, J.P., and Klein, D.A. (1999) Water Microbiology, McGraw-Hill Co. Inc., New York. 876-882.

[3] Gadgil, A. (1998). Drinking Water in Developing Countries, Annual Reviews of Energy and the Environment; 23: 253-286.

[4] Chauhan, P.K.S., and Paliwal, R.K. (2009): Study of Seasonal Variation of Heavy Metals Concentrations in Bed Sediments of Yamuna River, Current World Environment, Vol. 4(2), 439-442 (2009).

[5] Georgia, C. (1999). Water Storage, Journal of Water and Health. FN176. September 20, 2015.

[6] BIS (Bureau of Indian Standards) 10500, Indian standard drinking water specification, second revision, 2012.

[7] Mohanan Neethu, Manju E.K, and Jacob Sonia (2017): The effect of different types of storage vessels on water quality, International Journal of Innovative Research in Science, Engineering and Technology, vol. 6, 10, October (2017), ISSN (Online): 2319-8753 ISSN (Print): 23476710.

[8] Ogbozige F.J., D.B. Adie and F.B. Ibrahim (2015): Chemistry of Potable Water during Storage: the NorthWestern Nigeria Perspective, International Journal of Scientific \& Engineering Research, Vol. 6, June-2015, ISSN 2229-5518.

[9] Anf, H. Ziadat (2005). Impact of Storage Tanks on Drinking Water Quality in Al-Karak Province, Jordan Journal of Applied Science, Vol. 5(4), January 2005, PP 634-638 ISSN 1812-5654.

[10] Majesty Duru, Chioma Amadi, Benjamin Amadi, Chijioke Nsofor and Humphrey Nze (2013): Effect of Different Storage Vessels on Water Quality, Global Research Journal of Science, Vol. 2(2), 9-13, 2013, ISSN: 2276-8300.

[11] Schafer Cynthia A. And Mihelcic James R. Mihelcic (2012): Effect Of Storage Tank Material And Maintenance On Household Water Quality, Journal - American Water Works Association, Vol. 104, Issue9, September 2012, Pages E521-E529.

[12] Chalchisa Derara, Megersa Moa, and Beyene Abebe (2017): Assessment Of The Quality Of Drinking Water In Storage Tanks And Its Implication On The Safety Of Urban Water Supply In Develoning Countries. Environmental System Research, Article number: 12, 04 April 2017.

[13] Naddafi, K, Mahvi, AM, Nasseri, S, Mokhtari, M, Zeraati, H (2005). Evaluation of the Efficiency of Clay Pots in Removal of Water Impurities, Iranian Journal Environmental and Health Science Engineering, Vol. 2(2), PP- 12-16, 13 September 2005. 